\title{
PROFESSIONAL DEVELOPMENT WITHIN TEACHER LEARNING COMMUNITIES
}

\author{
Vanessa Moreira Crecci" \\ Universidade Estadual de Campinas (UNICAMP), Campinas - SP, Brasil \\ Dario Fiorentini"* \\ Universidade Estadual de Campinas (UNICAMP), Campinas - SP, Brasil
}

\begin{abstract}
This article aims to relate the concepts of professional development and professionalism projections to different kinds of teacher learning communities. In order to do so, we address a discussion based on descriptions of different ways of organizing these communities. Then we convey the subjacent features of borderland communities in which researchers, teachers, and future teachers work in collaborative ways without any regulations set by the university or the school. The end of the discussion shows that, although the methodologies seem innovative, it is worthwhile to conduct systematic evaluations of the careful formative and reflection processes that are concerned with the subjacent aspects of teaching learning communities.
\end{abstract}

Keywords: professional development; teacher learning communities; borderland communities; professionalism.

\section{DESENVOLVIMENTO PROFISSIONAL EM COMUNIDADES DE APRENDIZAGEM DOCENTE}

RESUMO: Neste artigo, temos por objetivo relacionar projeções de desenvolvimento profissional e de profissionalidade a diferentes tipos de comunidades de aprendizagem docente. Para tanto, realizamos uma discussão a partir da descrição de diferentes modos de organização dessas comunidades. Em seguida, discorremos sobre as características subjacentes às comunidades fronteiriças, nas quais pesquisadores, professores e futuros professores trabalham de modo colaborativo, sem a regulação da universidade ou da escola. Ao final desta discussão, conclui-se que, por mais que as metodologias sejam aparentemente inovadoras, tornam-se necessárias avaliações dos processos formativos e reflexões cuidadosas sobre os aspectos subjacentes às comunidades de aprendizagem docente.

Palavras-chave: Desenvolvimento profissional. Comunidades de aprendizagem docente. Comunidades fronteiriças. Profissionalidade.

\footnotetext{
" $\mathrm{PhD}$ in Education from the State University of Campinas. Collaborate of FE/Unicamp.

E-mail:< vancrecci@gmail.com >.

" $\mathrm{PhD}$ in Education from the State University of Campinas. Professor at the State University of Campinas.

E-mail:<dariofiore@unicamp.br $>$.
} 


\section{INTRODUCTION}

Many countries such as Brazil, USA, Canada, Chile, New Zealand, England, Portugal, and China have encouraged the establishment of teacher learning communities in an attempt to make the actual practice of teachers the focus of teaching processes. In this context, we note that the number of professional development experiences which are made possible by participation in different kinds of teacher learning communities increase every year. Teacher education processes that are grounded in initiatives such as lesson study, self-study, and action research, which is a part of practical research, tend to encourage the formation of these spaces. Based on this, the characteristics and underlying assumptions of these communities can be analyzed.

In this scenario, it is noted that such communities emerge and are motivated based on different understandings of the concepts of "learn better" and "teach better" (COCHRAN-SMITH; LYTLE, 2002). The ways in which teacher learning communities organize and design various perspectives of professional development enable teachers to be and live in the profession in various ways.

In this article, we aim to relate projections of professional development and professionalism to different kinds of teacher learning communities. In order to do so, we held a discussion based on the different meanings of the concepts of "teacher learning communities," "professionalism," and "professional development." The borderland community's underlying features are also introduced in this article. Finally, this article also describes and examines how researchers, academics, and future teachers work collaboratively in these communities.

\section{TEACHER LEARNING COMMUNITIES AND THEIR DESCRIPTIONS}

The teacher learning communities have received different nomenclatures: "communities of practice," "inquiry communities," "communities of teachers," "professional teaching community" etc. If these adjectives are not enough, there is also the polysemous word "community", which can be used to designate a number of collective, physical spaces (e.g., poor communities) or groups (e.g., ethnic or religious groups). Although widely used in other fields such as linguistics, philosophy, sociology, and anthropology, the term "community" is relatively new to the traditional literature on teacher education, professional development, and educational change (COCHRANSMITH; LYTLE, 2002). Scholars from different scientific fields have attributed a variety of underlying meanings to this term. 
In the field of philosophy, Chaui (1994, p. 377) understands community as "a group or a community where people know each other, are known by first name, have daily 'face to face' contact, share the same feelings and ideas, and have a common destiny". For the author, the time spent in the community is slow paced, and transformations are rare and usually caused by external events that affect them. On the other hand, society is a collective that is internally divided into groups and social classes, which contain isolated individuals.

Grossman, Wineburg and Woolworth (2001) indicate the association between the idea of community and a harmonious collective life, which is achieved through religions, and cultural and philosophical traditions, in which individuals work collectively for the common good.

Discussing the use of this idealized conception of philosophy, Abbagnano (2012) points out that the concept of community includes some connotations that lend themselves to the use purpose, since it seems clear that there is no such thing as a pure community and or a pure society:

[...] and the need to make a distinction in this regard is not motivated by observation, but by aspiration toward an ideal. Therefore, after it was used in sociology (Simmel, Cooley, Weber, Durkheim, and others), this term's meaning has undergone transformation till it took on its current usage in contemporary sociology: the distinction between social relations of a local type and those of a cosmopolitan type. This distinction is purely descriptive of behavior that is linked to the community in which one lives-either behavior that is restricted by communities or behavior that is oriented or open toward a wider society. (ABBAGNAMO, 2012, p. 192)

According to the studies of Cochran-Smith and Lytle (2002), in literary theory the term "interpretive community" has been used by Stanley Fish to refer to a network of people with similar perspectives of meaning, whereas in sociolinguistics, the term "speech community" has been used by anthropologists to refer to groups of people who engage in specific contexts. In their review, the authors also point out the "discourse communities" that are characterized as groups of readers and writers who become networks for quotes and allusions.

The authors point out that in the education field, the idea of community has been used in different ways in theory and research and that in the social sciences, the term denotes groups of people who are involved in certain types of work or activity and connected by a common purpose. According to this perspective, community members usually construct meanings and share signs and ideas about the enterprise in which they are engaged. A similar perspective was expressed by Wenger (2001), in which he identified three basic 
characteristics that constitute a community of practice and defined them as common interest, mutual interaction and commitment, and common practice that unites the participating members.

Based on these basic characteristics indicated by Wenger (2001), Fiorentini (2009) analyzed a collaborative group of mathematics teachers. The author concludes that the mutual commitment shared by the participants in joint practices of reflection and research influences their mathematics teaching and learning practices in schools (common interest). The author concludes that the mutual commitment shared by the participants in joint practices of reflection and research influences their mathematics teaching and learning practices in schools (common interest). According to Fiorentini (2010), participation from Wenger's (2001) perspective comprises the process by which the subjects of a community share, discuss, and negotiate meanings concerning what they do, speak, feel, think, and produce together. Thus, participating in a community of practice involves engaging in a community activity as an active and productive member. This implies appropriating the group's practices, knowledges, and values.

According to Imbernon (2009), a community of practice for permanent teacher education would be a group of professors and teachers that exchange ideas, share reflections with each other, and learn about their practice together. The community can be considered formative if participant teachers are able to develop their own culture within the group, and not only reproduce standardized versions that reflect the dominant social culture or academic perspectives.

Given the design that Wenger (2001) proposed for the analysis of everyday practices - school or non-school-in the broadest sense, we understand that, in addition to proposing communities of practice, it is necessary to make qualifications for and analyze these spaces and the emerging practices in these communities.

Grossman, Wineburg and Wooworth (2001), considering experiences in schools, also discuss the professional development of teachers in communities. According to the authors, communities must provide members with moments of dialogue and confidence, thus providing them with opportunities to look at multiple contexts involving teachers' work. They also recognize that the group needs to establish a joint history, configuring itself as a "community of memory" in which members weave "constitutive narratives." Joining a community, according to these studies, involves agreeing to disagree in a democratic way.

Developing discussions on communities and teacher training, Hargreaves (2010) is concerned with qualifying professional learning 
communities' goals and highlights the fact that many books, training programs, and guides already recognize the importance of the development of these spaces. These communities can increase teacher reflectivity. However, they can also focus too heavily on the exclusive purpose of raising student's tests scores, often at the expense of their literacy. For this reason, Hargreaves identifies and analyzes the different types of professional learning communities and categorizes them into two subgroups: (1) containment and control communities and (2) empowerment communities. The first group includes communities that support practices for controlling teachers and teaching practice, while the second group supports practices for encouraging and empowering teachers and their teaching practice.

\section{DIFFERENT PERSPECTIVES ON TEACHER LEARNING COMMUNITIES}

Cochran-Smith and Lytle (2002) assume that the concept of teacher learning communities can refer to an intellectual space, a particular group of people, and even a physical space sometimes. In this sense, communities are intellectual, social, and organizational configurations that support the continuous professional growth of teachers, providing them with opportunities to think, talk, read, and write about their daily work, including its social, cultural, and political aspects in a planned and intentional manner.

Cochran-Smith and Lytle's (2002) studies show that the three concepts of teacher knowledge, teacher learning, and professional practice coexist in educational policy, research, and practice, and that these ideas are invoked by differently positioned agents to justify very different approaches in order to improve teaching and learning through communities.

Cochran-Smith and Lytle (1999, 2002) explain that these ideas can be simplified based on the function knowledge takes on in relation to teacher practices in order to teach and learn. Based on the authors' work, we express three perspectives of teachers' knowledge as follows: "knowledge-for-practice"; "knowledge-in-practice"; and "knowledge-of-practice."

In order to learn for practice (knowledge-for-practice), experts build knowledge that is taught to teachers who then apply them in their practices. In the second design (knowledge-in-practice), it is assumed that learning and knowledge are constructed through practice in a tacit way through teachers' reflections on their practices. In the third concept (knowledge-of-practice), emphasis is placed on the 
interconnected relationship between practical knowledge, and formal or theoretical knowledge. Thus, it is assumed that the knowledge that teachers need to teach well is produced when they use their own practice as a context for research or analysis, and make interpretations and analyses using knowledge produced by other specialists.

Based on the knowledge-of-practice conception, CochranSmith and Lytle (1999) assume that the knowledge that teachers must teach well emanates from systematic research about the subject of how teachers teach and how students learn. It can also be built collectively in local communities. Further, in this paper, we discuss each of these three perspectives on professional development, professionalism and the teacher's role. We then study the perspective underlying borderland communities, which include researchers, academics, and pre-service teachers.

We start by connecting the Cochran-Smith and Lytle (1999, 2002) perspectives of learning and knowledge to professional development and professionalism in teaching. The significance of teaching learning communities emerges through a process of interaction between teachers and the subject. Cochran-Smith and Lytle (1999) warn about the relationship of the conceptions of knowledge and teacher learning, and we point out that none of the professional development initiatives can be "use as examples as a 'pure type' $[. .$.$] each reflects what we understand to be the dominant ideas$ that animate the initiative and also reflects the unique ways these ideas are played out in particular contexts and at particular points in time" (COCHRAN-SMITH; LYTLE, 1999, p. 253). Using this perspective, Cochran-Smith (cited FIORENTINI and CRECCI, 2016) points out that the communities have been called by different terms:

[...] professional learning communities, inquiry communities, teaching learning communities. But their names do not tell us how they operate and are not good or bad in themselves. It depends on what happens within these communities and the questions they ask and try to answer. However, depending on their implementation, they are sometimes empty structures, and not all developments that occur within them are positive. (FIORENTINI; CRECCI, 2016, p. 518).

In most cases, the underlying characteristics of teacher learning communities and practices are not explicit and often those responsible for managing these practices do not tend to question their own assumptions or how they interfere in the community's decisions and initiatives. The ways in which such formative processes happen are often naturalized within the institutions. 


\section{PROFESSIONALISM AND PROFESSIONAL DEVELOPMENT FOR PRACTICE}

In recent decades, international and national research began to criticize professional development projections based on individual learning processes. This led to the demand for and recognition of a learning perspective within teacher learning communities. Initially it was thought that only change in the professional development practice structures would ensure substantial changes. However, currently there are different conceptions and professional development practices even when they occur in communities (HARGREAVES, 2010).

Cochran-Smith and Lytle (2009) suggest that the concept of the teacher learning community has become very common and that this popularity has led to important new opportunities for teachers to learn from each other but that this has also led to the proliferation of policy initiatives, neither of which always focus on students' learning.

In professional development for practice perspectives, teachers have access to formal knowledge and have the opportunity to learn more content, educational theories, and strategies designed by experts. From that point of view, teachers are enabled to teach better when they know more. As a result, the teacher learning community promotes knowledge, helps teachers develop professionally, and allows teachers to access and implement this knowledge, that is, to translate and put into practice what they purchase from experts outside of the classroom (COCHRAN-SMITH; LYTLE, 2002).

The teaching practice laid down in these communities involves the appropriate and competent use of knowledge acquired a priori (COCHRAN-SMITH;LYTLE, 1999). Therefore, the professionalism of the teacher should be informed by academic theories and the knowledge systematized by the academic community:

The idea here is that competent practices reflects the state of the art; that is, highly skilled teachers have deep knowledge of their content areas and of the most effective teaching strategies for creating learning opportunities for students. Teachers learn this knowledge through various preservice and professional development experiences that provide access to the knowledge base (COCHRANSMITH; LYTLE, p. 254, 1999).

According to this perspective, teachers are able users and not generators of knowledge (COCHRAN-SMITH; LYTLE, 1999), assuming the teachers action chiefly involves the implementation of decisions taken by experts.

Morgado (2005, p. 34) identified this teaching projection and called it technical professionalism: it provides a teacher who "applies 
the rules that are derived from scientific knowledge to achieve certain predefined purposes." It starts with the premise that "the technical rules should guide the action of the subject. Teaching comes down to the mere application of standards and techniques derived from specialized knowledge" (p. 35). In addition, teachers must utilize knowledge "reproductive practices, used for students to embody the goals that guide their work" (p. 38).

When teachers are involved in communities that collectively aim to learn strategies and techniques to improve the performance of pupils in external tests, as identified by Hargreaves (2010), such professional development communities adopt the perspective of knowledge for practice. While there may be investigative communities to consider the test results, they need to have a critical perspective, be systematic, and connect the tests to larger contexts.

As participants in professional development practices that focus on understanding the teacher as coach and applier of the knowledge generated by experts, it is likely that these professionals find it difficult to "address and resolve the unpredictable dilemmas and conflict situations faced in the course of educational activity" (MORGADO, 2005, p. 40). For this reason, other conceptions of the teaching profession such as the "reflective teacher" were envisioned. We will discuss these conceptions in the next subsection.

\section{PROFESSIONALISM AND PROFESSIONAL DEVELOPMENT IN PRACTICE}

When learning and teachers' knowledge occur in practice, it is assumed that knowledge is built tacitly. This is the most important knowledge source for the profession. To improve teaching and enable teachers to professionally develop such a pragmatic perspective, it is necessary to work in communities with other teachers (COCHRAN-SMITH; LYTLE, 2002). It is assumed that teachers learn when they reflect on good teaching practices, that is, choose strategies, organize classroom routines, make decisions, create structure learning situations, and reflect upon their own achievements (COCHRAN-SMITH; LYTLE, 1999).

The practice of teachers is understood as a craftsmanship, so that the teaching profession the competent teachers know, to the extent that is expressed or conveyed in the practical art, the role of their own reflections about the practice in the investigation of the practice and narratives about practice. Teaching is understood in this perspective as a process of 
$[\ldots]$ in the ongoing actions of expert teachers as they choose among alternative strategies, organize classroom routines, and make immediate decisions as well as set problems, frame situations, and consider/reconsider their reasoning. To improve teaching, then, teachers need opportunities to enhance, make explicit, and articulate the tacit knowledge embedded in experience and in the wise action of very competent profissionals (COCHRAN-SMITH; LYTLE, p 262, 1999).

If, in the above perspective, the teachers were users of knowledge, they are seen as the designers and architects of this action (COCHRAN-SMITH; LYTLE, 1999). These ideas find resonance in Schön understanding about the teacher as reflective practitioner. Their teaching professionalism is built through this process of reflection in action, where

[...] a reflective teacher allows himself to be surprised by what the student does. Secondly, he reflects on this fact, that is, thinks about what the student said or did, and simultaneously seeks to understand why he was surprised. Then thirdly, he recasts the problem raised by the situation; maybe the student is not slow in learning, but on the contrary, is accomplished in complying with instructions. Fourth, the teacher performs an experiment to test his new hypothesis; for example, he puts forward a new issue or undertakes a new task to test his hypothesis about the way of thinking of his student. This process of reflectionin-action does not require words (SCHÖN, 1992, p. 83).

This professional development perspective based on reflection has received some criticism. First, it is recognized that there was an excessive use of the word "reflection" with relation to teacher education. According Morgado (2005), this overuse of the term often did not result in any special experiences and, in most cases, turned into an expression of an empty slogan. Second, Schön's ideas were criticized for not designing "a model that encompasses institutional change and/or social factors, focusing only on individual practice" (MORGADO, 2005, p. 48).

Currently, we have seen questions about the quality of undergraduate programs for teachers in the United States and elsewhere, (COCHRAN-SMITH et al., 2012). The proposals that focus on the professional development of teachers exclusively with regard to school communities gain strength. There is no substantial dialogue with the academic community. In these spaces, in general, the educators have the function of organizing spaces for teachers to talk about their issues. Often the position involves more than just listening to the discussions and stimuli; rather, it involves negotiating other forms of development practices for teaching and learning. 


\section{PROFESSIONALISM AND DEVELOPMENT OF PROFESSIONAL PRACTICE}

The third approach relates to the concept of knowledge-ofpractice, in which the knowledge that teachers need to teach well is generated when they deal with their classrooms and schools as places for intentional inquiry, while taking the knowledge produced by others as material for research and interpretation:

[...] knowledge emerges from the conjoined understandings of teachers and others committed to long-term highly systematic observation and documentation of learners and their sense making. To generate knowledge that accounts for multiple layers of context and multiple meaning perspectives, teach- ers draw on a wide range of experiences and their whole intellectual histories in and out of schools (COCHRAN-SMITH; LYTLE, 1999, p. 278).

Then we assume that teachers learn and develop professionally "when they generate local knowledge of practice by working within the contexts of inquiry communities to theorize and construct their work and to connect it to larger social, cultural, and political issues" (COCHRAN-SMITH; LYTLE, 2002, p. 2465).

It is therefore assumed that the teacher learns and develops professionally by participating in communities that have a policy of conducting and/or investigating systematic and deliberate research on teaching and learning. In this case, the investigative community should be used as a space to discuss the many aspects of teaching practice.

Cochran-Smith and Lytle (1999, p. 279) which comprise

\footnotetext{
When work in communities is based on knowledge-of-practice-whether that work is referred to as teacher research, action research, or practitioner inquiry-the goal is not to do research or to produce "findings," as is often the case for university researchers. Rather, the goal is understanding, articulating, and ultimately altering practice and social relationships in order to bring about fundamental change in classrooms, schools, districts, programs, and professional organizations.
}

Communities take their responsibility seriously and are "passionate in relation to student learning, their chances in life, and in relation to a change in policies and structures that limit students' access to these opportunities" (ibid).

In this context, the teaching profession is based on inquiry as stance. Because of the political relationship with the profession, there is increased responsibility towards the communities in which teachers are involved. The premise of this approach is that teachers can generate knowledge and learning collaboratively in teacher 
learning communities. May be critical attitudes toward the theories can conceived out of their contexts by changing the power relations between schools and universities.

May be critical attitudes toward these theories can be constructed out of their contexts by changing the power relations between schools and universities. In these inquiry communities, professional development experiences take place by asking and answering questions about the practices of teachers and trainers and the systematization of these practices. Investigative practices in investigative communities enable teachers and trainers to plan activities to be performed in the classroom, develop teaching materials, write stories about ways of teaching and learning, share activities they have developed, conduct studies on emerging issues of pedagogical practice, such as signifying the literature area.

In inquiry communities, teachers and educators work collaboratively to transform the curriculum and disciplines; critically examine the content and assessments as well as act as critical readers and conscious consumers of materials and programs; and develop valid approaches to identify and interpret a series of significant educational outcomes (COCHRAN-SMITH; LYTLE, 2009).

Members seek and build new knowledge to examine ways of teaching and learning in schools. Cochran-Smith and Lytle (2009) point out that, in recent decades, many discussions have debated whether teaching is or is not a profession and if teachers may or may not legitimately be considered professionals. According to the authors, teachers are already professionals, although many do not believe they can be considered as such, even if they are employed in oppressive working conditions. The professionals are engaged in daily activities, relational and uncertain, which take place under conditions of constant change. The authors stress the need for a new conception of professional practice in education and conceive a construct they call the investigative approach.

Based on this notion, they recognize the collective understanding of teachers and point out that they are inserted in inquiry communities. They take the inquiry approach in relation to knowledge and practice. The authors propose that teachers should go beyond performing sporadic research in a given period and suggest that teachers need to develop a way of employing investigative teaching.

Toward this end, they talk about four aspects related to the concept of inquiry approach: 1) a perspective of local knowledge 
in global contexts; 2) an expanded view of practice; 3) inquiry communities as a means or primary medium to adopt a theory of action; and 4) social justice.

On the first point, Cochran-Smith and Lytle (2009) theorize about the concept of inquiry approach. They recognize that local knowledge generated by teachers in inquiry communities may be an answer to the broad issues that affect other teachers.

The second aspect involves the vision of expanded practice covers student learning as well the ongoing investigations of students, teachers, and leaders in aspects of knowledge construction, cultural, intellectual, relational and political (COCHRAN-SMITH; LYTLE, 2009). With regard to the third aspect, Cochran-Smith and Lytle (2009) point out that, by participating in investigative communities, teachers have the possibility of creating what they call "action theory," which involves not only individuals but also communities. In this sense,

\footnotetext{
The essential purposes and functions of inquiry communities are to provide rich and challenging contexts for practitioner learning over the professional life span as well as making available productive locations for linking communities of educators with larger change efforts, both nationally and internationally (COCHRAN-SMITH; LYTLE, 2009, p 140).
}

Finally, they discuss a fourth aspect of the inquiry approach, and consider that, by participating, investigative communities of teachers are "they are working both within and against the system an ongoing process, from the inside, of problematizing fundamental assumptions about the purposes of the existing education system and raising difficult questions about educational resource, processes, and outcomes" (COCHRAN-SMITH, LYTLE, 2009, p. 154). In this sense, the ultimate purpose of inquiry as stance, always and in all contexts, is to improve student learning and their chances of participation and contribution toward a different and democratic society.

\section{PROFESSIONAL DEVELOPMENT IN BORDERLAND COMMUNITIES}

Fiorentini (2013) identified three basic types of inquiry communities: school, academic, and borderland. According to the author, academic inquiry communities being institutionally governed by the university, can be endogenous (focused on their theoretical problems and not affiliated with the school practices), colonizing of school practices, or collaborative. In turn, the school inquiry communities, being that normally schools grounds, can also 
be endogenous, open to collaboration and partnership with the university, or be colonized by the university, which assumes the role of transmitting and inculcating academic knowledge. Additionally, on the border, they point out that normally teachers have more freedom of action and have relative freedom in setting their own agenda,

$[\ldots]$ the border is a free place where interested parties from different communities can meet, venture forward, construct and question knowledge, and also carry out research. The borderline, however, is also a place of danger, a locale to transgress, a place to defy that which has been established in schools and academia. Since its participants come from various origins, the meetings tend to be interspersed with narratives of events that have occurred in the original communities. Still, what is produced and learnt in the borderline communities ends up having an appreciable impact on the personal and professional lives of each participant (FIORENTINI, 2013, p. 157).

In the case of borderland communities, we are not talking about the regional limits that separate two different territories from each other. Rather, we are talking about the borderland area that forms when two different worlds meet. Even the notion of frontier, which we know to be the boundary between two different areas, can be problematic.

According Zientara (1989), the term frontier "indicated the part of the territory in front, i.e., the banks" (p. 307). The author, therefore, points out that the notion of a border as the separation between two regions is mistaken. For the author, "boundaries separate human communities but can also determine a new particulargenre" (ibid). In this sense, the people who live in a border zone help to create a community founded on particular interests, and maintain between them, on this side and the other side of the border, an intense communication; and they also often live with contraband (ZIENTARA, 1989).

Anzaldúa (1987) points out that this place across borders is constituted as an "indeterminate space created by the emotional residue of an unnatural" limit. For the author (ibid), this space is in a constant state of transition Clandinin and Rosiek (2006), draw on Anzaldúa's idea, which views the border areas not in terms of being not clear or clear but as being blurred by regions that overlap and merge. Some geographical perspectives also consider the border area as indefinite, using their own dynamics. They suggest that border areas:

Are areas in which the local and the international intermingle establishing links and creating their own dynamics, built and reinforced by border towns. They contain the identities and national cultures of each country involved, and together build, rework, and constitute another culture and different identity, thus being capable of recreating a new place with regional aspects. These regions do not respect the existing barriers because there is action and interaction by border agents, and this stimulates informal border dynamics (SOUZA, 2009, p. 106 - 107). 
When discussing the boundaries of communities of practice, Wenger (2001) also points out that these cannot be understood as isolated from the world since "their stories are not internal, but in conjunction with the rest of the world" (p. 135). According to these researchers, it is the participation and reification ${ }^{1}$ in communities of practice that contributes to discontinuity boundaries. Designs involve the idea of boundary objects, including those brought by different communities to organize the connection in a single community, and the concept of the intermediary (brokering), which involves people carrying elements of one practice to another, i.e., the boundary objects.

According to Wenger (2001), a boundary object is not necessarily an artifact or coded information; instead, "the woods can be an environment boundary object, around which hikers, interested loggers, environmentalists, biologists, and the owners organize their perspectives and look for ways to coordinate them" (ibid, p. 140). In turn, brokers can establish new connections between communities of practice, facilitating coordination and agreement on the prospects; good brokers can even promote "new possibilities of meaning" (ibid, p. 142).

Thus, we can relate the map of these border areas to the idea of openness and connectivity in all its dimensions, which are "detachable, reversible, [and] susceptible to receive changes constantly. It can be torn, reversed, adapt to assemblies of any kind, be prepared by an individual, a group, a social formation" (DELEUZE; GUAT'TARI, 1996, p. 22).

What about professional development and professionalism in a borderland area? Fiorentini and Carvalho (2015) point out that this type of community functions not only as a place for not those who teach and those who learn, but also allows everyone to teach and learn based on their personal knowledge's. Each has its own horizon. In the figure below, the border community is arranged between the school and the university and is not regulated by any of the two contexts because it has its own regulations.

FIGURE 1. Between two worlds, Borderland Community

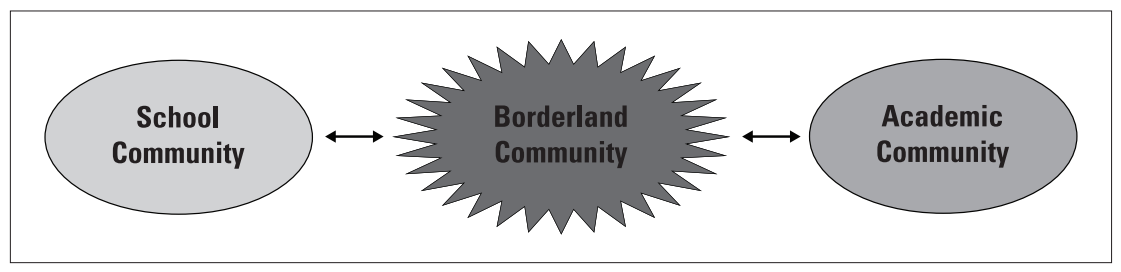

In borderland communities, there is the meeting of institutional cultures, mainly of school and academic cultures. However, there is 
also the meeting of subjective experiences that occur through the stories of lives, narrated by each of the participants and established in different scenarios' practices.

Sztajn et al. (2013), based on Wenger (1998), analyze professional development as a meeting between teachers and trainers. By analyzing the fieldwork and teachers' formations dating from the early years, the researchers concluded that teachers and trainers return to their communities of origin changed by the experience of the border.

Crecci (2016) analyzed the participation of mathematics educators (teachers, researchers, and trainers) in a border community called Grupo de Sábado (GdS). In her study, they found that participants narrated experiences in different areas related to their personal and professional lives other experiences, which produced different understandings about teacher and leaning mathematics. The reverberations arising from their participation in the border community are evident in their personal ways of being/living as mathematics educators, their problematical and investigative stance on the practice itself, their awareness about the possibilities and limits of scientific knowledge, and curricular and pedagogical teaching both in the school itself as well as other contexts.

The reverberations are also evidenced by the constitutions of other communities; the systematizations, theories, and publications of the participants, which help to promote change: the teaching and learning of mathematics in schools, making it more exploratory, problem-based and inclusive, especially for students public schools; the initial and continuing training of mathematics teachers, motivating them to be scholars and teachers in investigative communities; and in the training of new researchers, especially those conducting research on the practice itself.

Fiorentini (2009) used Bakhtin's (2003) surplus of vision design to analyze the meeting of basic school teachers with academic experts in the same community - a meeting known as Saturday Group. On the one hand, from experiences gained in the school environment, teachers signify the coming together of academic theorizing and actual experience.

(...) in the case of basic school teachers, since the formation of the group, they have negotiated meanings and perspectives with trainers and university academics on issues of teaching practice in mathematics and the teaching in public schools in the current context. Although the Academy spokesmen brought the group questions that helped produce curiosity and problematized the practice of the elementary school teachers, these, when making reference to their places in schools, manifested a vision surplus on academic theorizing, because they had 
knowledge and experiences related to mathematics teaching in public and private schools. They also had knowledge of the conditions of teaching productions in these schools, seeing what can or cannot be done in school practice, which usually does not know inside (FIORENTINI, 2009, p. 234 - 245).

On the other hand, when the students met the basic school teachers, they printed a vision surplus in relation to the basic school teachers, and made connections to the theoretical and scientific contributions

\begin{abstract}
(...) originating from the educational sciences and in particular the academic studies with regard to mathematics education there are interpretations and understandings that involve the first set of practices, experiences, and knowledge of seconds. I think, however, that the greatest academic vision surplus is the domain of the methodological processes of research and the questioning or denaturalization of existing school practices (FIORENTINI, 2009, p. 235).
\end{abstract}

In these border communities, both teachers and students give evidence of "construction and development of a teaching profession, interactive and reflective" (FIORENTINI, 2009, p. 251). Recounting his own experience within one of these communities with trainers, researchers, and teachers, Cochran-Smith (2013) points out that these are important areas where different communities can learn together and generate knowledge as part of an emerging movement. In the experiments that were conducted, participating members of these investigative communities were encouraged to engage in the practice studies, self study, action research, and other forms of research.

\title{
SOME FINAL WORDS
}

As much as the methodologies are apparently innovative, they are necessary as systematic evaluations and exhibit careful reflections on aspects of teacher learning communities. The bureaucratization of the institutions often imposes restrictions on the routines of practitioners and teachers, and this, in turn, often prevents them from performing systematic reflections on the ultimate goals of their practices.

Cochran-Smith (cited FIORENTINI; CRECCI, 2016) warns us that communities can be named in various ways but that such nomenclatures do not tell us how they operate, nor do they reveal whether they can be considered good or bad. Therefore, it is necessary to observe what happens within these communities and what questions arise within them. In summary, it seems that the places and ways in which communities are implemented sometimes turn out to be spaces where all kinds of things can happen. 
Thus, although the spaces are formed based on certain assumptions, it is not possible to predict the learning that may take place and the understanding of its participants or how their trajectories constitute these communities. This does not mean that we should relativize the ways in which these spaces are made or think that there is nothing to be done since much will depend on the trajectory of each element involved. On the contrary, considering that we do not have full control of what will be the relationship that trainers and teachers establish within these communities, we must create environments in which all participants are able to expose aspects of themselves and explore their subjectivities. In these environments, the emergence of a different surplus vision is possible.

\section{REFERENCES}

ABBAGNANO, N. Dicionário de Filosofia. Tradução coordenada por Alfredo Bosi. São Paulo, WMF, 2012.

ANZALDUA, G. Bordelands/La frontera. San Francisco: Aunt Lute, 1987.

CHAUÍ, M. Introdução à história da filosofia: dos pré-socráticos a Aristóteles. São Paulo: Cia das Letras, 1994.

CLANDININ, D. J; ROSIEK, J. Borders, tensions and borderlands in narrative inquiry. Handbook of narrative inquiry: mapping a methodology. Sage: Thousand Oaks, 2006.

COCHRAN-SMITH, M. Composing a Research Life. Action in Teacher Education. 34(2): p. 99-110, 2013.

COCHRAN-SMITH, M.; LYTLE, S. L. Teacher Learning Communities. In: Encyclopedia of Education 2nd Edition. J. Guthrie (ed.). New York: Macmillan, 2002.

COCHRAN-SMITH, M.; LYTLE, S. L. Inquiry as Stance: Practitioner Research in the Next Generation. New York: Teachers College Press, 2009.

COCHRAN-SMITH, M.; LYTLE, S. L. Relationships of knowledge and practice: Teacher learning in communities. Review of Research in Education, Washington, v. 24, p. 249305, 1999.

CRECCI, V. M. Desenvolvimento profissional de educadores matemáticos participantes de uma comunidade fronteiriça entre escola e universidade, 2016. $325 \mathrm{f}$. Tese de Doutorado, Faculdade de Educação, Unicamp, Campinas, 2016.

DELEUZE, G.; GUATTARI, F. Mil Platôs. Rio de Janeiro: Editora 34, v. 1, 1996.

FIORENTINI, D. Learning and professional development of the mathematics teacher in research communities. Sisyphus Journal of Education, v.1, n. 3, p.152-181, 2013.

FIORENTINI, D. Aprendizagem profissional e participação em comunidades investigativas. In: Seminário Práticas Profissionais dos professores de Matemática. Lisboa. 2013. Instituto de Educação da Universidade de Lisboa. Anais do Seminário Práticas Profissionais dos professores de Matemática, Lisboa, p. 01 - 26, 2013.

FIORENTINI, D. Desenvolvimento Profissional e Comunidades Investigativas. In: DALBEN, A.; DINIZ, J.; LEAL, LEIVA, L. SANTOS, L. (org.). Convergências e tensões 
no campo da formação e do trabalho docente: Educação Ambiental; Educação em Ciências; Educação em Espaços não-escolares; Educação Matemática. 1ªed.Belo Horizonte: Autêntica, v. 1, p. 570-590, 2010.

FIORENTINI, D. Quando acadêmicos da universidade e professores da escola básica constituem uma comunidade de prática reflexiva e investigativa. In: FIORENTINI, D; GRANDO, R. C.; MISKULIN, R. G. S. (org.). Práticas de formação e de pesquisa de professores que ensinam matemática. Campinas: Mercado de Letras, p. 233-255, 2009.

FIORENTINI, D.; CARVALHO, D. L. O GdS como lócus de experiências de formação e aprendizagem docente. In: FIORENTINI, D.; FERNANDES, F. L. P.; CARVALHO, D. L. (org.). Narrativas de Práticas de Aprendizagem Docente em Matemática. São Carlos: Pedro \& João Editores, p. 15-37, 2015.

FIORENTINI, D.; CRECCI, V. M. Interlocuções com Marilyn Cochran-Smith sobre aprendizagem e pesquisa do professor em comunidades investigativas. Rev. Bras. Educ., Rio de Janeiro, v. 21, n. 65, p. 505-524, Junho 2016.

GROSSMAN, P.; WINEBURG, S.; WOOLWORTH, S. Toward a theory of teacher community. The Teachers College Record, New York, v. 103, n. 6, p. 942-1012, 2001.

HARGREAVES, A. Leading Professional Learning Communities: Moral Choices Amid Murky Realities", Hargreaves, A. In: BLANKSTEIN, A. M., HOUSTON, P.D. \& COLE, R.W. Sustaining Professional Learning Communities. Thousand Oakes: Corwin Press, p. $175-198,2010$.

IMBERNÓN, F. Formação Permanente do Professorado: Novas Tendências. São Paulo: Editora Cortez, 2009.

MORGADO, J. C. Currículo e Profissionalidade Docente. Portugal: Porto Editora, 2005.

SZTAJN, P.et al. Mathematics professional development as design for boundary encounters. ZDM, v. 46, n. 2, p. 201-212, 2013.

WENGER, E. Comunidades de práctica: aprendizaje, significado e identidade. Barcelona: Paidós, 2001.

ZIENTARA, B. Fronteira. Enciclopédia Einaudi, v. 14, p. 306-317, 1989.

\section{NOTES}

${ }^{1}$ By the term "objectification" the author refers to the concrete form of the experience, for example, write a book, create a method, etc. (WENGER, 2001).

Submission: 29/11/2016

Approbation: 13/04/2017

Contact:

Faculdade de Educação da Unicamp

Rua Bertrand Russell, 801

Cidade Universitária Zeferino Vaz

Campinas |SP|Brasil

CEP 13.083-865 